\title{
Papers
}

\section{The evolution of betterment in the United Kingdom}

Received (in revised form): 26 October 2007

\section{Anthony Andrew}

is the Chief Property Adviser at the Scottish Government. The views expressed are his own and do not necessarily reflect the views of the Scottish Government.

\section{Michael Pitt}

is Professor of Facilities Management and Head of Business Development in the School of the Built Environment at Liverpool John Moores University.

\section{Matthew Tucker}

is a Research Associate in the Property, Facilities, and Operations Management Research Group in the School of the Built Environment at Liverpool John Moores University.

\begin{abstract}
The purpose of this paper is to review the new planning gain supplement's place in the history of the collection of betterment in the UK and understand how the intertwining strands of revenue collection and planning betterment have interacted to produce different forms of legislation to address the issue. The paper looks historically at the legislation used in past attempts to collect betterment to understand the origins of the planning gain provisions. The legislation in the past has tended to emerge mainly from one or other of the two strands of thought, namely revenue production or to achieve planning aims. The present arrangements appear to have both planning agreements and the revenue arrangements of planning gain supplement running side by side. The paper provides an understanding of this history of the subject and the evolution of betterment within the UK. It is of use to practitioners in placing the current legislation in the context of the historical perspective. The paper updates and extends existing material to cover planning gain supplement introduced by the new act, and puts it in a different context. It should be of interest to academic readers keeping up with the latest developments in legislation, policy makers and the betterment debate, and of interest to practitioners who want background to this new area of work.
\end{abstract}

Matthew Tucker

School of the Built Environment Liverpool John Moores University Cherie Booth Building Byrom St, Liverpool L3 3AF, UK Tel: + 44(0)1512312630 Fax:+44(0)1512312815 E-mail: m.p.tucker@ljmu.ac.uk

\section{Keywords:}

planning gain, betterment, land taxation, planning gain supplement, Barker Report, taxation of development gain

Journal of Retail and Leisure Property (2007) 6, 273-280.

doi:10.1057/palgrave.rlp.5100076 


\section{INTRODUCTION}

In the report 'Review of the Housing Supply' one of the recommendations was to consider collecting planning gain from increased development values on residential land. ${ }^{1}$ This reignited a debate that has ebbed and flowed for the best part of 95 years.

Two interwoven themes in that debate have formed a counterpoint over the last century. Is betterment to be harvested through a tax collected by the Inland Revenue for the Treasury or is it a local government levy associated with the planning system to be garnered locally for the benefit of the vicinity? This mildly arcane argument took on new life after devolution when the Scotland $\mathrm{Act}^{2}$ made general taxation a matter reserved for government at Westminster but planning a devolved matter for the Holyrood Parliament in Scotland.

\section{BRIEF EARLY HISTORY OF BETTERMENT}

Lloyd George, the Chancellor of the Exchequer sparked fierce controversy with his proposals for 'Duties on Land Values through an "Increment Value Duty". 3 This was paid on "the increment value of any land a duty, called increment value duty, at a rate of one pound for every complete five pounds of that value' ${ }^{3}$ after 30 April 1909. It covered transfers, transfers on death and leases. It was general taxation to be collected like a stamp duty. It covered increases in existing use value and development value. ${ }^{3}$ It led to the formation of the Inland Revenue Valuation Office and was repealed in 1920.

During Ramsey MacDonald's administration, a further attempt was made to harvest betterment by tackling the problem from a planning perspective in the Town and Country Planning Act. ${ }^{4}$ The preamble to the Act said it was 'to authorise the making of schemes with respect to the development and planning of land, whether urban or rural' ${ }^{4}$ The betterment question was not central to the legislation. However, Section 21 provided:

'21(1) Where by the coming into operation of any provision contained in a scheme, or by the execution by a responsible authority of any work under a scheme, any property is increased in value, the responsible authority, if within twelve months after the date on which the provision came into operation or such longer period as may be specified ......may....recover in value from the person whose property is so increased in value an amount not exceeding seventy-five per cent of the amount of that increase.'4

There were also provisions for injurious affection further into the complex section (Section 21(1)). ${ }^{4}$ This legislation was locally based and focussed on development value and this is reflected by the higher rate of tax. This scheme was repealed in 1940 .

\section{BRIEF POST WAR HISTORY OF BETTERMENT}

During the war years of 1939-1945 substantial work was done setting the agenda for the reform of post war Britain. Behind it was the idea that if 
national planning could win the war, it could also drive the agenda for the peace in social security, healthcare and land use and resource planning. Among this work were the Barlow, Scott and Uthwatt reports. In 1940 the Barlow Commission ${ }^{5}$ reported on the industrial population structure of Britain and its imbalances, the Scott Report ${ }^{6}$ covered development and the needs of agriculture and the rural economy and finally the Uthwatt Committee ${ }^{7}$ reported on compensation and the recovery of betterment where the use of land was to be publicly controlled.

From the Scott Report flowed the compensation and betterment provisions of the Town and Country Planning Act. ${ }^{8}$

The development rights in land were nationalised and landowners were compensated by the provision of a $£ 300 \mathrm{~m}$ national fund that was to pay out on accepted claims by 1953 at 1947 values. Landowners were left with existing use rights and third schedule development rights under the Town and Country Planning (Scotland) $\mathrm{Act}^{9}$ which allowed rebuilding, modest expansion and agricultural and forestry uses. (These are termed Sixth Schedule rights in the parallel legislation in England and Wales). A landowner would seek planning consent and pay to the Central Land Board a development charge of 100 per cent of the difference between the land's value in its existing use and its value in its proposed new developed use. At the same time public sector bodies could buy land for their statutory functions at existing use value. There was equality of treatment between those selling on the market and those selling under the shadow of compulsory purchase.

According to Wyndham Thomas, ${ }^{10}$ there was a debate about whether the development charge should be set at 100 per cent, with Lewis Silkin arguing for 70 per cent to give landowners an incentive to sell and Sir Malcolm Trustram Eve who preferred 100 per cent. The latter won.

In 1951 the Conservative party came to power and the debate was renewed on slightly different terms as Wyndham Thomas records:

'Rab Butler, perhaps the best post-war conservative chancellor, wanted to keep the development charge, but at $70 \%$ or even $60 \%$. At this level, he believed a market in development land could be restored and a substantial revenue flow secured. But Harold Macmillan, housing and planning minister and much more sympathetic to the landowner lobby, wanted the charge abolished; though he argued strongly to retain existing use value as compensation for publicly acquired land. ${ }^{10}$

By 1953 there were $£ 350 \mathrm{~m}$ in claims against the fund. However, following the change in administration the conservative government decided that payment would be made only on the refusal of planning consent. Harold Macmillan won the argument and the development charge disappeared. However, this created a two-tier market where those who sold on the open market were well rewarded with substantial development value and those who sold to the public sector received modest existing use often only agricultural value. This dichotomy caused massive discontent.

Five years later the government responded with the Town and Country Planning (Scotland) $\mathrm{Act}^{11}$ which re-established market value as the price 
for land acquired by compulsory purchase. Where the public sector use proposed was one for which there was no market such as health or education the landowner could apply to the planning authority for a Certificate of Appropriate Alternative Development which would indicate the use to which it would otherwise have been put and this was used as the basis for compensation. Under the 1959 approach, codified in the Land Compensation (Scotland) $\mathrm{Act}^{12}$ any increase in value due to the scheme itself is disregarded.

Land values increased significantly and as memories of wartime shortages receded concern about preserving agricultural land melted in face of the need for better housing and the profit motive. Farmland sold at high prices for development at a time when capital gains were untaxed.

\section{THE NEW TOWNS}

Another product of the war years was the New Towns Act. ${ }^{13}$ This provision does not often feature in accounts of betterment, but it provided for the establishment of New Town Development Corporations which had planning powers as well as the ability to acquire land using compulsory powers. So land could be acquired at existing use value or agricultural value and when the corporation had developed it, it sold or leased it on retaining the whole of the increment in development value for reinvestment. Many criticisms have been made about social and design aspects of the new towns. However, they were very effective financially. According to Gardiner:

'only did the Government get back the $£ 4.7$ billion it had loaned the new towns, plus interest, but the Commission for New Towns (in England) was also left with land worth $\mathrm{f}_{1}$ billion at present prices. ${ }^{14}$

Armed with planning and compulsory purchase powers, proprietary rights in land and access to reasonably priced government capital they were formidable developers who delivered what was asked of them. What is rarely acknowledged is that they are the sole successful collectors of betterment in the nation's history - collecting 100 per cent of the development value and ploughing it back into infrastructure and much needed development of homes, industrial and commercial properties for the benefit of the community.

Before the 1959 Act they could acquire at existing use value even land that patently had development value. Even after 1959, as they had planning powers they could acquire land that had no obvious development value, and then award themselves consent later.

\section{THE LAND COMMISSION}

The 1964 election brought in the Labour administration that set up the Land Commission. ${ }^{15}$ It aimed to regulate the development land market and harvest some betterment value. It had discretionary powers to buy land zoned for development in local plans. It was to collect betterment 
levy at 40 per cent of the increase in development value. It also permitted public bodies to buy land net of betterment levy.

Although effectively a national tax gathering body, the Land Commission was outside the control of the Inland Revenue. Strangely it was also outside the control of the Ministry of Housing and Local Government that had responsibility for planning matters.

The betterment levy was charged on the development value, not any increase in the current use value. It was payable by the person who realised the chargeable gain, normally the seller of the land, at the point of disposal or the start of material development. It was not levied at the award of planning consent. It was expected to apply to only 10-15 per cent of transactions. ${ }^{16}$

The Land Commission had an unhappy life, unloved by powerful Whitehall interests, disliked by landowners, unpopular with the local planning authorities and having problems recruiting good staff. By 1970 Wyndham Thomas records:

'it had bought 2800 acres of land with 9000 acres in the pipeline. And it had collected or assessed $f_{72 \mathrm{~m}}$ of betterment levy,$-{ }^{10}$

\section{THE EARLY $1970 S$}

The 1970 election brought in Edward Heath's Conservative administration that wound up the Land Commission. In the early 1970s there was a boom and development land values rose. This created public concern and debate.

The government's response was to tax development gains as income rather than capital. This was achieved by the Finance $\mathrm{Act}^{17}$ Section 38 (2) which treated development gain as profits chargeable under Case VI of Schedule D from 17 December 1973. This meant that instead of taxation under the Finance Act 1965 as capital gains at 30 per cent they were taxed at the punishing levels of income tax that prevailed in the early 1970s. This was called Development Gains Tax.

This did not last long as the economic and political landscape began to change. There was an oil crisis, industrial unrest and strikes by miners leading to power cuts and a three-day week and two elections in 1974. This brought in a Labour administration that addressed the problem afresh.

\section{DEVELOPMENT LAND TAX AND THE COMMUNITY LAND ACT}

The new administration replaced the expedient device of DGT with a more comprehensive solution that cleverly intertwined a national tax with a planning-oriented land acquisition system. Development Land Tax (DLT) was designed to harvest development values until all land with potential for development or redevelopment was publicly owned. ${ }^{18}$ Until that point local authorities were encouraged to use the powers under the legislation to buy development property, until the day when this was made obligatory by a ministerial order. The final phase was to be when all development land and buildings were taken into public ownership when 
they came up for development and were bought at existing use value and DLT was no longer needed. The tax rate was 80 per cent of development value, but the base value was existing use value with some allowances which left an incentive to bring land forward. A specialist Development Land Tax Office was established in Middlesbrough and there was a Land Authority for Wales to undertake land assembly and promote the supply of developable land in the principality.

When the Conservative administration was elected in 1979, the Community Land $\mathrm{Act}^{19}$ was repealed. This was unsurprising as it had struggled to achieve its aims in difficult economic times and did not sit comfortably with a market-led vision. What was unexpected was that the Chancellor Geoffrey Howe did not abolish DLT immediately but simply cut the rate of tax to 60 per cent. Neither was the Land Authority for Wales abolished. It had a useful role not unlike the Scottish Development Agency, Scottish Enterprise and English Partnerships as a site assembler and development facilitator that was pretty much self-funding.

At this point it seemed that a cross party consensus had been reached on the taxation of development gain through this typically British compromise.

However, in 1985, Nigel Lawson, the Chancellor of the Exchequer abolished it among other reasons because it was costly to administer.

\section{DEVELOPMENT VALUE POST 1985}

Since then development value has been taxed under the general capital gains tax provision at the prevailing tax rate. Critics point out that this is not particularly effective as there are significant loop holes that taxpayers can legitimately use to minimise the tax burden on their development gains.

Some benefits have been garnered for the public sector through planning agreements under Section 75 of the Town and County Planning (Scotland) Act $1997 .{ }^{20}$ When the planning authority receives an application from a developer it discusses with them contributions to the social infrastructure requirements that result from the scheme. This can include financial contributions to extra school classrooms, offering land for affordable housing, undertaking widening of road junctions or provision of roundabouts. This varies from scheme to scheme and between planning authorities. The agreed contribution is then formalised in a Section 75 planning agreement. Developers complain that the system is unpredictable and time and labour intensive. Local authorities welcome the help with vital infrastructure. However, as it is an ad hoc local levy it does little for those areas where there is no development. They rely on the Chancellor's largesse from whatever he gathers through capital gains tax and passes down by way of grant to local authorities. The link in these cases is theoretical.

\section{PLANNING GAIN SUPPLEMENT}

Following the 'Review of Housing Supply', 1 the question of the systematic collection of a share of development value has re-emerged as a 
direct result of one of Kate Barker's recommendations, the question of whether there should be a planning gain supplement administered nationally by the Inland Revenue or a rationalised local planning-based approach growing out of planning agreements has become a matter of active debate.

\section{PLANNING TARIFFS}

Intervening in the debate following the Barker Report, the British Property Federation (BPF) issued a position paper ${ }^{21}$ arguing for planning tariffs rather than the Treasury's proposed planning gain supplement. A tariff would:

'* A tariff based system will achieve the Government's desire for increased infrastructure funding from the private sector in a relatively straightforward and cost effective manner;

* A tariff set locally will be formulated in line with the strategic infrastructure requirements outlined in Local Development Frameworks, which will minimise the risk of them being set at an inappropriate level;

* Tariffs will provide developers with greater certainty, since their level will be known up front and can be factored into development costs. Tariffs will also allow $\mathrm{S.106}$ payments to be scaled back to those measures needed to mitigate the direct impacts of development;

* A tariff based system, by distributing tariff revenues at the local and regional level, will ensure that local communities receive the benefits from development in their areas;

* A tariff based solution could be collected from all types and sizes of developments and not be constrained in accessing only a small group of large developers. This would spread the cost of delivery of infrastructure more equitably. ${ }^{21}$

The acceptance of the taxation of development gain by the BPF was perhaps a surprise, but was also a measured response to a fairly strong consensus that some share of betterment needed to go to the public purse.

Shortly after, in October 2005 the Royal Institution of Chartered Surveyors (RICS) published a report by Tony Johnson and Chris Hart also responding to the Barker Report Debate. It argued that the Planning Gain Supplement would be unworkable. ${ }^{22}$ They argued other approaches were better such as a tariff-based approach with the system of planning agreements. If it had to be a tax, the Finance $\mathrm{Act}^{17}$ development gains tax was preferable and simpler albeit funds would go to central rather than local government.

In the face of the very mixed response to its proposals for Planning Gain supplement, the Treasury spent all of 2006 and most of the following year in exhaustive consultations with industry bodies, local government and the devolved administrations. These were brought to a conclusion in October 2007. 


\section{THE PRE BUDGET REPORT AND COMPREHENSIVE SPENDING REVIEW 2007}

HM Treasury announced that:
'The Government has consulted extensively about the best way to ensure that local communities receive more of the benefits from planning gain, to invest in necessary infrastructure and transport. Legislation in the forthcoming Planning Reform bill will empower Local Planning Authorities in England to apply new planning charges to new development alongside negotiated contributions for site- specific matters. The charges will be used to finance the infrastructure proposed by the development plan for the area, including regional and sub-regional infrastructure. The housing Minister will publish further details in a statement today. Legislation implementing Planning-gain Supplement, which was a new levy proposed by Kate Barker's review of Housing Supply in 2004 and the subject of extensive consultation, will therefore not be introduced in the next Parliamentary session. ${ }^{23}$

For the time being it seems that the harvesting of planning gain will remain a local planning function, and the centralised revenue collection vision has receded.

\section{References}

1. Barker, K. (2004). Review of Housing Supply, Final Report, HM Treasury, London.

2. Scotland Act 1998 c. 46.

3. Finance (1919-10) Act, 1910 c. 8.

4. Town and Country Planning Act 1932 c. 48.

5. Barlow Report: Report on the Geographical distribution of the Industrial Population, Report and Evidence, HMSO, 1940.

6. Scott Report: Report of the Committee on Land Utilisation in Rural Areas, HMSO, 1942.

7. Uthwatt Committee: Expert Committee on Compensation and Betterment, Final Report, HMSO, 1942.

8. Town and Country Planning Act 1947 c. 51.

9. Town and Country Planning (Scotland) Act 1947 c.53.

10. Bill, P. (ed.) (2004). Building sustainable communities: capturing land development value for the public realm, A collection of papers published by the Adam Smith Institute.

11. Town and Country Planning (Scotland) Act 1959 c. 70.

12. Land Compensation (Scotland) Act 1963 c. 51.

13. New Towns Act 1946 c. 68.

14. Gardiner, J. (2004). The new towns - a regeneration and renewal special report. Regeneration and Renewal, 29 October 2004.

15. Land Commission Act 1967 c. 1.

16. Scottish Development Department (1967). Betterment Levy - a guide for Scottish estate agents and surveyors.

17. Finance Act 1974 c. 30.

18. Development Land Tax Act 1976 c. 24.

19. Community Land Act 1975 c. 77.

20. Town and Country Planning Act 1990 c. 8.

21. British Property Federation (2005). Don't kill the goose! The case for tariffs not tax, A BPF Position Paper, August 2005.

22. Johnson, T. \& Hart, C. (2005). The Barker review of housing supply and planning gain supplement, A Report published by the Royal Institution of Chartered Surveyors. October 2005.

23. HM Treasury (2007). Pre-budget report and comprehensive spending review 2007, Press Notice 1, 9 October 2007, http://www.hm-treasury.gov.uk/pbr_csr07_press01.cfm. 